\title{
Exclusive Dealing in General Business Practice
}

\author{
Timothy J. Brennan \\ Graduate School of Arts and Sciences \\ George Washington University \\ Washington, DC
}

Exclusive dealing is where a firm or individual deals with a worker, supplier, purchaser, or retailer on the condition that the latter works only for the firm or individual in question. Examples illustrate the breadth of this practice. Most companies expect their managerial and professional workers not to work for other firms, certainly not for other firms in the same business or in the same capacity for another employer. One would be very surprised to fund a firm permitting its, say, vice president for sales to do the same work for another firm, even for one not a competitor. Even blue collar or line employees are usually hired with the implicit if not explicit expectation that they will work solely for the employer. The decision to hire a worker to do a job or to have the job done by an independent contractor could be viewed as little more than a decision as to whether the firm wants its workers to "exclusively deal" their labor.

These arrangements are hardly limited to labor settings. A partnership frequently will establish contractual expectations that the partners not engage in related business outside the partnership. Firms may often expect their suppliers not to supply similar products to other firms. A pen manufacturer, for example, might buy from an ink manufacturer, under the condition that this ink manufacturer not sell similar ink to another pen company. The very idea of "vertical integration" presupposes the idea that the production stages within the firm work exclusively for the firm. One would regard exceptional that, say, an automobile plant was used to produce cars for another car company. A "firm," in fact, could usefully be defined as that set of production facilities and workers committed to work exclusively with each other.

An important special case in which exclusive dealing may be applied is in the manufacturer/retailer relationship. In one direction, a manufacturer may grant a retailer the exclusive right to sell a product in a particular geographic area. A case in point is a franchise arrangement, where a firm like McDonald's grants a franchise to a. firm along with an agreement not to permit another McDonald's not to deal with another food outlet within the marketing area. In the other direction, a manufacturer may employ a retailer on the condition that it sell only the manufacturer's products. Looking at the McDonald's example in this direction, McDonald's will typically expect its franchisee not to sell Burger King products, pizzas, or other non-McDonald's food items.

Journal of Business Strategies, Volume 5, Number 2 (Fall 1988) 


\section{Literature Review}

One would think that the study of "exclusive dealing" would have been motivated by this ubiquity, and that it would be understood by economists and students of industrial organization in that light. Unfortunately, this has not been the case. Since exclusive dealing predated sophisticated economic analysis of contractual practices, it was assumed that exclusive dealing must have been an indicator or manifestation of some kind of antitrust-like anticompetitive activity. It seemed that a firm only sacrifices profits by restricting the ability of its employees, retailers, or input supplicrs to engage in other business opportunities, since these parties need to be compensated for agreeing to face the restriction. Therefore, it seemed that a firm would impose exclusive dealing requirements on another only if it could do so without added compensation, i.e., by "foreclosing" its competitors from access to the individual or firm now "tied up" under the exclusive dealing requirement.

Because of its association with antitrust law, the emphasis of the exclusive dealing literature ([3], [7], [13], [14], [16], [21]) has been on whether exclusive dealing can enhance or protect a firm's market power. Fortunately, however, exclusive dealing is among a number of non-price "vertical restraints" that have become the subject of considerable scrutiny and rethinking, both in the courts and in the academic literalure ([1], [8], [10], [17]). Antitrust courts and legal commentators over the past ten years ([1], [4], [15], [17], [18], [20]) have come to view non-price vertical restraints more benignly than in the past. As we have seen, exclusive dealing is far more widespread than can credibly be attributed to antitrust considerations.

Even if the courts now view exclusive dealing in a more generous light, a firm still may wonder whether to institute exclusive dealing. Not only may the costs and benefits of doing so be subtle, but the decision may be controversial among the affected parties. In the conventional "exclusive dealing" case, retailers may not want a major supplier to cut them off if they continue to sell another manufacturer's product, and will likely demand to be compensated for their lost business opportunities.

Our purpose here is to illuminate the tradeoffs inherent in the general exclusive dealing situation, where antitrust-related concerns are not relevant. We note that an obvious cost to the firm who wants an employee, retailer, or supplier to deal exclusively on its behalf is that this firm will have to compensate these "agents" for the lost business opportunities sacrificed in the exclusivity. The gains, on the other hand, follow when we consider the relationship between a firm and these "agents" in terms of "conflict of interest." "Conflict of interest" is a term more familiar in politics, philosophy, or law rather than economics. As we discuss below, however, exclusive dealing or limitations on outside activities to mitigate conflicts of interest can enhance the operating efficiency of a vertical relationship.

\section{"Principal/Agent" Analysis}

A useful way to identify and understand the costs and benefits involved in exclusive dealing is to look at what is called a "principal/agent" setting. The "principal" is 
the party employing an "agent" to perform a service or supply a product. Our question is when is it in a principal's (manufacturer's, wholesaler's, manager's) interest to have its agents (suppliers, retailers, workers) work exclusively on its behalf, assuming it must keep each agent as well off as it would be if it retained the freedom to engage in unrelated "outside" activities. The following table lists some "principal/agent" relationships in which exclusive dealing may become significant, along with an cxplanation as to why there may be need for additional compensation for the agent and why the principal might be willing to pay the price.

Table 1

Exclusive Dealing Settings

\begin{tabular}{|llll|}
\hline Principal/Agent & $\begin{array}{l}\text { Nature of } \\
\text { Exclusion }\end{array}$ & $\begin{array}{l}\text { Need for } \\
\text { Compensation }\end{array}$ & $\begin{array}{l}\text { Motive for } \\
\text { Exclusivity }\end{array}$ \\
\hline Manufacturer/Supplier & $\begin{array}{l}\text { Supply output } \\
\text { only to } \\
\text { manufacturer }\end{array}$ & $\begin{array}{l}\text { Lost business } \\
\text { from sales } \\
\text { to other firms }\end{array}$ & $\begin{array}{l}\text { Keep trade } \\
\text { secrets from } \\
\text { competitors }\end{array}$ \\
Wholesaler/Retailer & $\begin{array}{l}\text { Sell only the } \\
\text { wholesaler's } \\
\text { product }\end{array}$ & $\begin{array}{l}\text { Deprived of } \\
\text { other sales } \\
\text { opportunities }\end{array}$ & $\begin{array}{l}\text { Devote sales cffort } \\
\text { solely toward } \\
\text { wholesaler's } \\
\text { product }\end{array}$ \\
Manager/Worker & $\begin{array}{l}\text { Work exclusively } \\
\text { for the employer }\end{array}$ & $\begin{array}{l}\text { Lost outside } \\
\text { income }\end{array}$ & $\begin{array}{l}\text { Eliminate } \\
\text { distractions, } \\
\text { shirking } \\
\text { opportunities }\end{array}$ \\
\hline
\end{tabular}

These examples have a number of properties in common. First is the conflict of interest between the agent and the principal. The principal wants the agent to do something the agent finds unprofitable or undesirable. The supplier wants to sell to other manufacturers; the manufacturer doesn't want the supplier who learns about the downstream production process to use the knowledge to benefit the manufacturer's competitors. The retail dealer wants to sell other products; the wholesaler wants the dealer to promote and service his products exclusively. The employee wants to make money moonlighting; the manager wants the worker to reserve her energies for the company's exclusive use.

Second, it is difficult for the principal to monitor the agent's behavior to see that these conflicts are not important. A manager often has no way of knowing how good a job the worker is doing; poor results could reflect either outside circumstances beyond the worker's control or lack of effort due to the pursuit of other employment. The wholesaler cannot easily attribute lost market share to improvements in the image of a competitor's product or laxity in the sales efforts of its dealers. The manufacturer has no way of knowing whether a competitor discovered a trade secret on its own or learned it from a common supplier. 
Both the conflict and the inability to monitor are critically important in rationalizing exclusive dealing. Obviously, if the agent's desires coincided with the principal's, the principal would have no reason to impose restrictions on the agent's actions. But even where there is a conflict of interest, a principal could in theory monitor the agent's effort and compensate him or her on the basis of the observed behavior. The ability to base rewards on monitored behavior can give the agent incentives to act as the principal prefers. If the worker knew, for example, that her payment would be based upon how quickly she responded to the company's needs, there would be no inherent problern in letting her moonlight. One could simply base her reward on her performance.

\section{Exclusive Dealing Settings}

In an earlier paper [2], I constructed models of this principal/agent relationship to investigate further these benefits of exclusive dealing. Unlike prior analyses of exclusive dealing ([6], [9], [10], [11], [12], [19]) we will not analyze effects beyond the principal and agent, e.g., whether exclusive dealing is inefficient because it promotes monopoly or excessive product differentiation. However, the discussion here may shed some light on antitrust issues by helping to understand when and why exclusive dealing would be instituted.

\section{Simple Conflict Settings}

Consider first a setting in which outside activities would discourage the agent, form acting in the interests of the principal. This is a characteristic common to all the scenarios set out in Table 1 . One would expect that it would always be in the interest of the principal to have the agent deal exclusively on its behalf. Principals, though, confront a tradeoff common to all these situations. The very fact of a conflict of interest means that the agent would rather be doing something other than what the principal wants it to do. It follows that the principal is going to have to compensate an agent for the opportunities it gives up when it makes an exclusive commitment on the principal's behalf.

This introduces two complications into the question of when exclusive dealing benefits the principal. The first is that the principal will have to decide whether the improved performance of the agent is worth the increase in compensation necessary to get the agent to act on its behalf. To take an example, suppose a high technology firm can hire engineers for $\$ 10,000$ less in annual salary if it permits them to take on outside consulting jobs or conduct independent research. It then has to decide whether it will get improvements in firm-specific effort worth the extra $\$ 10,000$ per engineer to get exclusive performance. It may not if, for example, the opportunity to do outside work complements the engineers' efforts on behalf of the firm, rather than diverting attention from them.

This might lead one to conclude that exclusive dealing is profitable only where the outside activity conflicts with the principal's desired activity. Conversely, one might also conclude that where the outside activity complements the principal's interests, 
exclusive dealing would never be instituted. Unfortunately, this need not be the case. Situations can be identified in which it may be in the principal's interest to either (1) institute exclusive dealing even where the ontside activities complement those in which the principal is most interested, and (2) permit conflicting activities even when they discourage performance of desired activities.

The reason these unintuitive findings may hold is subtle, having to do with the relationship between an agent's income and its incentive to work on the principal's behalf. Consider the engineer again. Suppose the more income an engineer has, the more the professor is willing to undertake new research opportunities that benefit the high technology firm. Note that this is not the same thing as paying the engineer more to work harder. Rather, the engineer's own willingness to undertake this effort is correlated with income, in that an engineer who is wealthy will put more time into research of his own volition, reducing the need for the high technology firm to monitor his behavior or linit his opportunities. If this positive "income effect" is strong, it may be in the high technology firm's interest to permit some outside activity to increase the engineer's income, even if the outside activity itself has a negative effect on firm-specific effort. The benefits to the high technology firm in getting more highly motivated engineers, by allowing them to earn outside income, would exceed the costs of the "distraction."

A similar line of argument shows that exclusive dealing may be imposed even where the outside activity is itself complementary if the "wealth effect" is strong but negative, i.e., more income makes acting in the principal's interest less attractive. These arguments can be generalized to all of the exclusive dealing situations displayed in Table 1 or discussed above.

\section{Provision of Support Services}

A more complex situation is one in which the principal can "invest" in the agent, e.g., when a manufacturer trains a dealer in the repair of his products. Exclusive dealing here can serve as a way in which the principal can capture the "return" on this investment; otherwise, it may not be provided. Consider a bicycle maker, for example, who would find its bicycles in greater demand if trained repairpersons were easily available. However, repair expertise need not be specialized to the manufacturer's own brand. Trained bicycle repairpersons could make it easier to get bicycles of any brand repaired, not just those of the manufacturer who provided the training.

If the services provided by the bicycle maker cannot be linked to his brand, the benefits of those services will be diffused over the market as a whole. Other manufacturers need not provide training; they can just "free ride" off the training already provided. If the training does not provide a competitive advantage to the bicycle maker, it will have little or no incentive to provide this training. Here, exclusive dealing can provide the restriction necessary to generate the advantage. A bicycle retailer would receive instruction on how to fux Brand $X$ bicycles only if he or she refused to carry any other brand for which this training would apply. In that way, 
other manufacturers cannot "free ride" off the repair training provided by Brand X's manufacturer.

Prevention of free riding has been the beneficial effect of exclusive dealing most discussed in the economic literature $([8],[10],[17])$. According to this story, increased outside activity by an agent discourages the provision of support services. If a bicycle dealer can sell other makes of bicycles, a manufacturer providing the training may "capture" less of the benefits of the training. The "income effect" discussed above comes in here in an interesting way, though. The more outside activity, the more income the agent can make in using that training, and the less the principal need pay to the agent. To rcturn to our example, the bicycle maker can reduce its compensation to its retailers if those retailers can make money by using training in the repair of other makes of bicycles. Because of this "income effect," the principal's incentive to provide support services to its agent may actually be enhanced if its agent is able to profit from these services in the provision of outside activities.

\section{Concluding Remarks}

To summarize, we have found that exclusive dealing is far from being an aberration present only in antitrust-related contexts. Rather, it is a common device used to mitigate conflicts of interest between principals and their agents who cannot otherwise be monitored or controlled. An important special case is when an agent would have the incentive to use special training or support services on behalf of other "principals." When the effect of outside activity on an agent's income is recognized, though, a number of counterintuitive possibilities could occur. Exclusive dealing may make sense even where outside activities complement work for the principal. It may not make sense even where there is a confict of interest, and some outside activity may make it more profitable to provide support services that might benefit other principals.

Before leaving the topic, we should consider the possibility that exclusive dealing might be a device to exploit an agent. For example, once someone has decided to work at a particular firm, personal and financial commitments may reduce his mobility to the point where the firm may not need to maintain his welfare at the originally "promised" level. One way would be to cut salaries, but salary is often set over time by exclusive contract. A more feasible opportunistic strategy would be to impose exclusive dealing rules after the worker is already committed to the firm. Such a change may get the worker to work harder for the firm without the need to compensate for lost earnings from foregone alternate employment opportunities.

The theory of this kind of opportunism is set out by Klein, Crawford, and Alchian [5]. While it may be in the principal's interest to take advantage of its agents' commitments, this will typically offer only short-run benefits, with potential long-run costs. A firm or wholesaler will not be able to continue to exploit its employees or retailers in this manner if it wants to recruit new agents or to retain those agents who are more mobile. It will have to promise salaries and compensation ex ante contingent upon the possibility of ex post exploitation, eliminating much of the gain and leaving only a mutually undesirable inefficiency. If the firm expects to be growing, it will find 
this kind of behavior detrimental to its long-run interests. Tightening anti-conflict rules in midstream may be inconsistent with plans for growth.

\section{References}

1. Bork, R. The Antitrust Paradox. New York: Basic Books (1978).

2. Brennan, T. "Exclusive Dealing and Conflict of Interest." Economic Analysis Group Discussion Paper 87-10. U. S. Department of Justice: Antitrust Division (1987).

3. Comanor, W. and H. E. Frech. "The Competitive Effects of Vertical Agreements." American Economic Review, Vol. 75 (1985), pp. 539-46.

4. Continental T. V. Inc., et. al. v. GTE Syivania Inc., 433 U.S. 36 (1977).

5. Klein, B., R. Crawford, and A. Alchian. "Vertical Integration, Appropriable Rents, and the Competitive Contracting Process." Journal of Law and Economics, Vol. 21 (1978), pp. 297-326.

6. Klein, B. and L. F. Saft. "The Law and Economics of Franchise Tying Contracts." Journal of Law and Economics, Vol. 28 (1985), pp. 345-61.

7. Krattenmaker, T. and S. Salop. "Anticompetitive Exclusion: Raising Rivals' Costs To Achieve Power over Price." Yale Law Journal, Vol. 96 (1986), pp. 20993.

8. Marvel, H. "Exclusive Dealing." Journal of Law and Economics, Vol. 25 (1982), pp. $1-25$.

9. Marvel, H. and S. McCafferty. "The Welfare Effects of Resale Price Maintenance." Journal of Law and Economics, Vol. 28 (1985), pp. 363-79.

10. Mathewson, G. F. "Incentives and Exclusive Dealing." Mimeo, University of Toronto Department of Economics (1986).

11. Mathewson, G. F. and R. A. Winter. "An Economic Theory of Vertical Restraints." Rand Journal of Economics, Vol. 15 (1984), pp. 27-38.

12. Mathewson, G. F. and R. A. Winter. "The Economics of Vertical Restraints in Distribution." In J. Stiglitz and G. F. Mathewson (eds.), New Developments in the Analysis of Market Structure. Cambridge, MA: The MIT Press (1986).

13. Mathewson, G. F. and R. A. Winter. "Is Exclusive Dealing Anti-Competitive?" American Economic Review, Vol. 77 (1987), pp. 1057-62.

14. Pittman, R. "Tying Without Exclusive Dealing." Antitrust Bulletin, Vol. 30 (1985), pp. 279-97. 
15. Posner, R. "The Next Step in the Antitrust Treatment of Restricted Distribution: Per Se Legality." University of Chicago Law Review, Vol. 48 (1981), pp. 6-26.

16. Schwartz, M. "Exclusive Dealing and Product Differentiation: What do Comanor and Frech Really Show." American Economic Review, Vol. 77 (1987), pp. $1063-68$.

17. Schwartz, M. and D. Eisenstadt. "Vertical Restraints." Economic Analysis Group Discussion Paper 82-8. U. S. Department of Justice: Antitrust Division (1982).

18. Standard Oil Co. of California v. United States, 337 U.S. 293 (1949).

19. Teiser, L. "Why Should Manufacturers Want Fair Trade?" Journal of Law and Economics, Vol. 3 (1960), pp. 86-105.

20. U. S. Department of Justice: Antitrust Division. Vertical Restraints Guides (1985).

21. Warren-Boulton, F. R. Vertical Control of Markets. Cambridge, MA: Ballinger (1978). 